\title{
Konya İlinde Özel Bir İşletmede Yetiştirilen Siyah Alaca Sığırların Bazı Süt Verim Özelliklerine Ait Fenotipik Parametre Tahminleri
}

\section{Omer Hashım Qasım JARSHAJI 1(D), Uğur ZÜLKADİR² \\ 1,2,Selçuk Üniversitesi Ziraat Fakültesi Zootekni Bölümü, KONYA \\ ${ }^{1}$ https://orcid.org/0000-0001-6053-7828, ${ }^{2}$ https://orcid.org/0000-0003-3243-4949 \\ $\triangle$ : uzulkad@selcuk.edu.tr}

\begin{abstract}
ÖZET
Araştırma Konya ili Karapınar ilçesinde bulunan özel bir işletmede yetiştirilen Siyah Alaca sığırlara ait fenotipik parametrelerin belirlenmesi amacıyla yapılmıştır. Araştırmada süt verimiyle ilgili olarak, sağımda geçen gün (SGG), 100 günlük süt verimi (YGSV), 200 günlük süt verimi (IYGSV), 305 günlük süt verimi (305GSV), sağım süresi (SS) ve elektrik iletkenliği (EI) değerlerine ait genel ortalamalar sirasiyla; $178.62 \pm 23.53$ gün, $3142.98 \pm 643.75 \mathrm{~kg}$, $5947.07 \pm 1439.92 \mathrm{~kg}, 6324.08 \pm 1769.29 \mathrm{~kg}, 342.048 \pm 139.107 \mathrm{sn}$ ve $5.0677 \pm 0.5255 \mathrm{mS} / \mathrm{cm}$ olarak tespit edilmiştir. Yüz günlük süt verimine etkisi incelenen faktörlerden buzağılama yılının ve buzağllama mevsiminin etkisi $\mathrm{P}<0.05$ seviyesinde, iki yüz günlük süt verimine etkisi incelenen faktörlerden buzağılama yılının etkisi $\mathrm{P}<0.01$ seviyesinde, üç yüz beş günlük süt verimine etkisi incelenen faktörlerden buzağılama yılının etkisi $\mathrm{P}<0.05$ seviyesinde, laktasyonda geçen gün (LGG) üzerine etkili faktörlerden laktasyon sırası, buzağılama yılı ve buzağılama mevsiminin etkisi $\mathrm{P}<0.01$ seviyesinde önemli bulunmuştur.
\end{abstract}

Development Characteristics of Holstein Friesian Calves between Birth to Four Months of Age Reared in a Private Farm in Konya Province in Ereğli District

\section{ABSTRACT}

The study was conducted to determine the phenotypic parameters of Holstein cattle bred in a private enterprise in Karapinar district of Konya province. In the study, the mean of milk yield, days in milk (DIM), 100-days milk yield, 200-days milk yield, 305-days milk yield, milking time and electrical conductivity were determined as $178.62 \pm$ 23.53 days, $3142.98 \pm 643.75 \mathrm{~kg}, 5947.07 \pm 1439.92 \mathrm{~kg}, 6324.08 \pm$ $1769.29 \mathrm{~kg}, 342.048 \pm 139.107 \mathrm{sec}$ and $5.0677 \pm 0.5255 \mathrm{mS} / \mathrm{cm}$, respectively. Effect of calving year and calving season on 100-days milk yield were found statistically significant $(\mathrm{P}<0.05)$. Effect of calving year on 200-days milk yield was also found statistically significant $(\mathrm{P}<0.01)$. Additionally, effect of calving year on 305-days milk yield was statistically significant $(\mathrm{P}<0.05)$, and effect of parity, calving year and calving season on days in milk were found statistically significant $(\mathrm{P}<0.01)$.

\section{Araştırma Makalesi}

Makale Tarihçesi

Geliş Tarihi : 16.05 .2019

Kabul Tarihi : 30.06 .2019

Anahtar Kelimeler

Siyah Alaca,

Fenotipik parametre,

Elektrik iletkenliği,

305 günlük süt verimi

\section{Research Article}

$\begin{array}{ll}\text { Article History } & \\ \text { Received } & : 16.05 .2019 \\ \text { Accepted } & : 30.06 .2019\end{array}$

\section{Keywords}

Holstein Friesian,

Phenotypic parameters,

Electrical conductivity,

305 days milk yield

To Cite : Jarshaji ÖHQ, Zülkadir U 2019. Konya İlinde Özel Bir İşletmede Yetiştirilen Siyah Alaca Sığırların Bazı Süt Verim Özelliklerine Ait Fenotipik Parametre Tahminleri. Tarım ve Doğa Derg 22(Ek Sayı 1): 162-168. DOI: 10.18016/ksutarimdoga.v22i49073.561738

\section{GİṘ’̧}

Türkiye'de 2017 yılı TÜIK verilerine göre 15.943 .586 baş sığır bulunmaktadır. Türkiye'nin toplam sığır varlığının \%90'ı kültür ırkı ve melezlerinden oluşmaktadır. Aynı kurumun verilerine göre 2017 yılı için kültür ırkı, melez ve yerli ırk sığırlardan bir laktasyonda elde edilen süt miktarı sırasıyla $3,861 \mathrm{~kg}$, $2,728 \mathrm{~kg}$ ve $1,307 \mathrm{~kg}$ iken tüm sığırların yıllık süt verim ortalaması ise 3,143 kg'dır (Anonim, 2018).
Türkiye için resmi istatistik kurumu tarafindan inek başına düşen yıllık süt veriminde yıllar itibariyle artış olsa da Avrupa Birliğine üye ülkelerin ortalamasından oldukça düşüktür.

Türkiye hayvan varlığı bakımından dünyanın en önde gelen ülkelerinden birisi olmasına karşın hayvan başına alınan verim bakımından ise gelişmiş ülkelerin gerisinde kalmaktadır. Türkiye'de yıllardır yürütülen ıslah çalışmaları ve teşvik programları sonucunda 
birim başına verimde önemli gelişmeler olmuştur ama istenen verim düzeyine ulaşlamamıştır. Ülke nüfusunun dengeli ve sağllklı beslenmesi için hayvancilık sektörünün gelişmesi büyük önem taşımaktadır (Uzman, 2000).

Türkiye'deki işletmelerin çok büyük bir kısmı küçük ölçekli işletmelerdir. $\mathrm{Bu}$ nedenle işletmelerden beklenen verimlilik tam anlamiyla sağlanamamaktadır. Orta ve büyük çaplı işletmeler de kültür ırkı hayvanlarla çalışmalarına rağmen Avrupa ülkelerinde sağlanan verimler alınamamaktadır. Bunda hayvanlara istemiş oldukları çevre faktörlerinin sağlanamaması neden olduğu gibi sürü yönetimi faaliyetlerinin tam olarak uygulanamaması da etkili olmaktadır. Bu nedenle işletmelerin zaman zaman kendilerini değerlendirerek eksikliklerini tespit etmeleri ve bunlara önlem almaları gereklidir. Bu bağlamda Konya ili Karapınar ilçesinde iki yıldır faaliyet gösteren bir işletme seçilmiş ve bu işletmenin döl ve süt verim özellikleri değerlendirilmiştir. Bununla işletmedeki eksiklikler belirlenecek ve önerilerde bulunulacaktır.

$\mathrm{Bu}$ çalışmanın amacı, Konya iline bağlı Karapınar ilçesinde bulunan özel bir işletmede yetiştirilen süt sığırlarının süt verim özelliklerinin ve bu verimlere etkili çevre faktörlerinin belirlenmesi amaçlanmaktadır.

\section{MATERYAL ve YÖNTEM}

Araştırmanın materyalini Konya ili Karapınar ilçesinde bulunan özel bir işletmede yetiştirilen 125 baş sağmal hayvanların iki yıllık verileri oluşturmuştur. Çalışmada süt verim özelliklerinden sağımda geçen gün (SGG), 100 günlük süt verimi (YGSV), 200 günlük süt verimi (IYGSV), 305 günlük süt verimi (305GSV), sağım süresi (SS) ve elektrik iletkenliği (EI) değerlerine ait veriler değerlendirilmiştir. Çalışmada kuruda kalma süresine ait güvenilir veri bulunamadığından değerlendirmeye alınmamıştır. İşletmede süt verimleri bilgisayara dayalı sürü takip programlarıyla kaydedilmektedir. Çalışmada bu programdan elde edilen verilerden yararlanılmıştır.

Söz konusu araştırmada incelenen özelliklere etkisi olduğu düşünülen çevre faktörlerinden mevsim faktörünün değerlendirilmesinde, mevsimlerin gruplandırılması Eylül, Ekim ve Kasım ayları 1. Grup (Sonbahar); Aralık, Ocak, Şubat ayları 2. Grup (Kış); Mart, Nisan ve Mayıs ayları 3. Grup (Ilkbahar); Haziran, Temmuz ve Ağustos ayları 4. grup (Yaz) olacak şekilde sınıflandırılmıştır. Buzağı cinsiyeti sinıflandırmasında ise, erkek buzağılara 1 ve dişi buzağılara 2 rakamı verilerek istatistik analizleri yapılmıştır. Çalışmada bazı veri gruplarında sağlıklı değerlendirme yapabilecek kadar rakam bulunmamaktadır.
Araştırmanın yapıldığı işletmede sabah ve akşam olmak üzere günde iki sağım yapılarak süt verimleri kaydedilmektedir. Bu kayitlardan yararlanarak süt verim özellikleri tespit edilmiştir. Sağımda geçen gün (SGG), 100 günlük süt verimi, 200 günlük süt verimi, 305 günlük süt verimi, sağım süresi ve iletkenlik değerlerine etkisi incelenen faktörlerde kullanılacak matematik modele laktasyonda geçen gün için örnek verilmiş olup diğer özelliklerin matematik modellerine gerekli faktörlerin eklenmesiyle veya çıkarılmasıyla model oluşturulacaktır.

Laktasyonda geçen güne etkisi incelenecek faktörlerin etkilerinin belirlenmesinde kullanılacak matematik model aşağıda verilmiştir.

Yijkl $=\mu+a i+b j+c k+b x i j k+e i j k l$

Yijkl = i. yılda, j. laktasyon sırasındaki, k. mevsimdeki ineğin laktasyonda geçen gün sayısı

$\mu=$ Populasyon ortalaması

ai $=$ i. yılın etki miktarı (a1: 2016, a2 :2017, a3 : 2018)

$\mathrm{bj}=\mathrm{j}$. laktasyon sirasının etki miktarı $(\mathrm{b} 1: 2, \mathrm{~b} 2: 3$, b3:4, b4: 5)

$\mathrm{ck}=\mathrm{k}$. mevsimin etki miktarı (k1: eylül, ekim, kasım (Sonbahar); k2 : aralık, ocak, şubat (K1ş); k3 : mart, nisan, mayıs (Ilkbahar); $\mathrm{k} 4:$ haziran, temmuz, ağustos (Yaz))

bxijk = Laktasyonda geçen günün 305 günlük süt verimine kısmi regresyon katsayısı

eijkl = Hata etki miktarl

Araştırmada elde edilen verilerin istatistik analizinde Harvey (1987) paket bilgisayar programı kullanılmıştır. İncelenen özelliklere ait en küçük kareler ortalamaları (EKKO), etki miktarları (EM) ve standart hataları (SH) tablolar halinde sunulmuştur. Faktör seviyeleri arasındaki farklılıklar Duncan çoklu karşılaştırma testi kullanılarak belirlenmiştir (Düzgüneş ve ark., 1993).

\section{SONUÇLAR ve TARTIŞMA}

\section{Süt Verim Özellikleri}

Süt verimi ile ilgili özelliklerde analiz edilmiş veri sayıları Çizelge 1'de verilmiştir. İşletme iki yıllık olduğu için her özellik için yeterince veri toplanamamıştır.

Çizelge 1. Süt verim özelliklere ait veri sayıları

\begin{tabular}{|l|c|}
\hline Süt Verim Özellikleri & Veri Sayıları \\
\hline Yüz günlük süt verimi & 104 \\
\hline İki yüz günlük süt verimi & 57 \\
\hline Üç yüz beş günlük süt verimi & 24 \\
\hline Laktasyonda geçen gün (LGG) & 96 \\
\hline Sağım süresi (sn) & 125 \\
\hline Elektrik İletkenliği (Eİ) & 125 \\
\hline
\end{tabular}

Yüz Günlük Süt Verimi

Yüz günlük süt verim değerine ait elde edilmiş olan genel ortalama $3142.98 \pm 643.75 \mathrm{~kg}$ olarak tespit 
edilmiştir. Yüz günlük süt verimine ait en küçük kareler ortalaması (EKKO), etki miktarı (EM) ve standart hata $(\mathrm{SH})$ değerleri Çizelge 2'de verilmiştir.

Yüz günlük süt verimine etkisi incelenen faktörlerden buzağılama yılının ve buzağılama mevsiminin etkisi önemli $(\mathrm{P}<0.05)$, laktasyon sirası ve buzağı cinsiyetinin etkisi ise önemsiz çıkmıştır. 2016 yılında az sayıda da olsa veri değerlendirmeye alınabilmiştir.

Çizelge 2. Yüz günlük süt verimine ait elde edilmiş olan EKKO, EM ve SH değerleri

\begin{tabular}{|c|c|c|c|c|}
\hline Etkili Faktörler & SD & $\mathrm{N}$ & $\mathrm{EKKO} \pm \mathrm{SH}$ & $\mathrm{EM} \pm \mathrm{SH}$ \\
\hline \multirow{5}{*}{ Laktasyon sirası } & 1 & 78 & $2701.25 \pm 175.65$ & $-286.22 \pm 148.37$ \\
\hline & 2 & 12 & $3141.17 \pm 224.52$ & $153.69 \pm 192.75$ \\
\hline & 3 & 3 & $2898.52 \pm 397.45$ & $-88.95 \pm 317.15$ \\
\hline & 4 & 4 & $2916.76 \pm 340.62$ & $-70.71 \pm 287.29$ \\
\hline & 5 & 7 & $3279.68 \pm 277.66$ & $292.20 \pm 235.06$ \\
\hline \multirow{2}{*}{ Buzağı cinsiyeti } & Erkek & 55 & $2979.54 \pm 178.25$ & $-7.93 \pm 66.13$ \\
\hline & Dişi & 49 & $2995.41 \pm 175.77$ & $7.93 \pm 66.13$ \\
\hline \multirow{3}{*}{ Buzağılama yılı* } & 2016 & 4 & $2244.38 \pm 353.55^{\text {В }}$ & $-743.09 \pm 244.41$ \\
\hline & 2017 & 79 & $3323.73 \pm 133.75^{\mathrm{A}}$ & $336.25 \pm 133.87$ \\
\hline & 2018 & 21 & $3394.31 \pm 213.10^{\mathrm{A}}$ & $406.83 \pm 172.50$ \\
\hline \multirow{4}{*}{$\begin{array}{l}\text { Buzağılama } \\
\text { mevsimi* }\end{array}$} & Sonbahar & 52 & $3208.06 \pm 181.32 \mathrm{~A}$ & $220.58 \pm 140.54$ \\
\hline & Kış & 6 & $2861.35 \pm 309.18^{\text {В }}$ & $-126.12 \pm 217.01$ \\
\hline & Ilkbahar & 7 & $3111.21 \pm 280.38 \mathrm{~A}$ & $123.73 \pm 214.71$ \\
\hline & Yaz & 39 & $2769.28 \pm 172.96^{\text {В }}$ & $-218.19 \pm 127.32$ \\
\hline
\end{tabular}

*:P<0.05, A,B: Aynı sütunda farklı harflerle gösterilen ortalamalar arasındaki farklar önemlidir

Buzağılama yılı dikkate alındığında 2016 yılında elde edilmiş olan ortalama 2017 ve 2018 yılında elde edilen ortalamalardan önemli derecede düşük çıkmıştır $(\mathrm{P}<0.05)$. Ortalamalar yıllar itibarıyla artmış olup bunda işletmedeki çevre şartlarının yıldan yıla iyileşmiş olması ve genetik yapıdaki iyileşmeler neden olmuş olabilir.

Mevsimler bazında ise en yüksek ortalama kış mevsiminde elde edilmiş olup bunu yaz mevsimi takip etmiştir. Mevsimler arası farklılıkta vejetasyon durumu etkili olmuş olabilir. Kışın çok fazla yeşil veya kuru ot bulunamadiğında hayvanlar kesif yem ağırlıklı beslenmekte bu da bir miktar verim artışına neden olabilmektedir. Yazın ise hayvanlar hem kesif hem de kaba yemi yeterince alabilmektedir. $\mathrm{Bu}$ da mevsimler arasında verim bakımından varyasyona neden olabilmektedir. Özellikle ilkbaharda doğumların olması istenen bir durumdur, ancak buradan görüldüğü üzere ilkbahar doğumlarının az olması bir problem teşkil etmektedir. Daha sağlıklı yorum yapabilmek için işletmenin ileriki yıllarda durumunu değerlendirecek kadar veriyi elde etmesi gereklidir. Buradaki veriler ancak mevcut durumu tespite yönelik olabilir.

Mevcut araştırmada elde edilmiş olan $3142.98 \pm$ 643.75 kg'llk ortalama Kaya ve Kaya (2003) ve Gürses ve Bayraktar (2012)'ın yaptıkları araştırma sonucunda elde ettikleri $2075 \pm 605 \mathrm{~kg}$ ve $2719.66 \pm 13.52 \mathrm{~kg}{ }^{\prime} \mathrm{llk}$ ortalamalardan yüksek bulunmuştur.

\section{İki Yüz Günlük Süt Verimi}

İki yüz günlük süt verimine ait genel ortalama 5947.07 $\pm 1439.92 \mathrm{~kg}$ olarak tespit edilmiştir. İki yüz günlük süt verimine etkisi incelenen faktörlere ait EKKO, EM ve Sh değerleri Çizelge 3’te verilmiştir. İki yüz günlük süt verimine etkisi incelenen faktörlerden laktasyon sırası, buzağ etkisi önemsiz, buzağılama yılının etkisi ise önemli bulunmuştur $(\mathrm{P}<0.01)$.

İki yüz günlük süt verimine etkisi incelenen faktörlerden buzağılama yılı dikkate alındığında 2017 yılının ortalaması 2016 yılına göre önemli derecede yüksek çıkmıştır. Bunda her iki yıldaki veri sayısının yetersiz olması yanında 2017 yılında işletmenin çevre şartlarındaki iyileşmelerde etkili olmuş olabilir. Bir fenotipin ortaya çıkmasında iki faktör etkilidir. Bunlar genotip ve çevre'dir. Çevre şartlarının düzeltilmesi hayvanların genotip değerlerinin ortaya çıkarılmasında etkilidir. Bu nedenle genotipe uygun çevre faktörlerinin mutlaka sağlanması gereklidir.

Mevcut araştırmada elde edilmiş olan $5947.07 \pm$ 1439.92 kg'llk ortalama Gürses ve Bayraktar (2012)'ın yaptıkları araştırma sonucunda elde ettikleri $5246.94 \pm 25.69 \quad \mathrm{~kg}$ 'lı $\quad$ ortalamadan yüksek bulunmuştur.

\section{Üç Yüz Beş Günlük Süt Verimi}

Ü̧ yüz beş günlük süt verim değerine ait elde edilmiş olan genel ortalama $6324.08 \pm 1769.29 \mathrm{~kg}$ olarak tespit edilmiştir. Üç yüz beş günlük süt verimine ait EKKO, EM ve Standart Hata değerleri Çizelge 4'te verilmiştir. Üৎ yüz beş günlük süt verimine etkisi incelenen faktörlerden laktasyon sırası, buzağı cinsiyeti ve buzağılama mevsiminin etkisi önemsiz, buzağılama yılının etkisi ise $\mathrm{P}<0.05$ seviyesinde önemli bulunmuştur. 
Çizelge 3. İki yüz günlük süt verimine etkisi incelenen faktörlere ait EKKO, EM ve SH değerleri

\begin{tabular}{|c|c|c|c|c|}
\hline Etkili Faktörler & SD & $\mathrm{N}$ & $\mathrm{EKKO} \pm \mathrm{SH}$ & $\mathrm{EM} \pm \mathrm{SH}$ \\
\hline \multirow{5}{*}{ Laktasyon sırası } & 1 & 33 & $4635.41 \pm 358.22$ & $-407.81 \pm 345.59$ \\
\hline & 2 & 9 & $5681.99 \pm 536.44$ & $638.76 \pm 482.84$ \\
\hline & 3 & 3 & $4156.94 \pm 892.62$ & $-886.28 \pm 718.52$ \\
\hline & 4 & 5 & $5344.40 \pm 690.69$ & $301.17 \pm 576.74$ \\
\hline & 5 & 7 & $5397.38 \pm 637.04$ & $354.15 \pm 534.38$ \\
\hline \multirow{2}{*}{ Buzağı cinsiyeti } & Erkek & 29 & $4935.62 \pm 395.29$ & $-107.60 \pm 198.13$ \\
\hline & Dişi & 28 & $5150.83 \pm 407.09$ & $107.60 \pm 198.13$ \\
\hline \multirow{2}{*}{ Buzağılama yılı** } & 2016 & 9 & $3774.95 \pm 545.31^{\mathrm{b}}$ & $1268.27 \pm 279.98$ \\
\hline & 2017 & 48 & $6311.50 \pm 320.75^{a}$ & $1268.27 \pm 279.98$ \\
\hline \multirow{4}{*}{ Buzağılama mevsimi } & Sonbahar & 7 & $5362.17 \pm 648.97$ & $318.94 \pm 481.07$ \\
\hline & Kış & 6 & $4864.34 \pm 691.13$ & $-178.88 \pm 505.20$ \\
\hline & İlkbahar & 12 & $4449.77 \pm 429.60$ & $593.45 \pm 411.67$ \\
\hline & Yaz & 32 & $5496.62 \pm 389.47$ & $453.39 \pm 303.33$ \\
\hline
\end{tabular}

$* *: \mathrm{P}<0.05$, a,b: Aynı sütunda farklı harflerle gösterilen ortalamalar arasındaki farklar önemlidir.

Çizelge 4. 305 günlük süt verimine etkisi incelenen faktörlere ait hesaplanmış olan EKKO, EM ve SH değerleri

\begin{tabular}{|l|l|l|l|l|}
\hline \multicolumn{2}{|l|}{ Etkili Faktörler } & N & EKKO \pm SH & EM \pm SH \\
\hline \multirow{4}{*}{ Laktasyon sırası } & 1 & 14 & $5048.60 \pm 876.43$ & $-2970.26 \pm 1277.91$ \\
\cline { 2 - 5 } & 2 & 5 & $7199.34 \pm 816.62$ & $-819.52 \pm 916.96$ \\
\cline { 2 - 5 } & 3 & 5 & $11808.66 \pm 2503.35$ & $3789.79 \pm 1936.19$ \\
\hline \multirow{3}{*}{ Buzağı cinsiyeti } & Erkek & 11 & $8054.50 \pm 831.50$ & $35.63 \pm 374.43$ \\
\cline { 2 - 5 } & Dişi & 13 & $7983.23 \pm 758.30$ & $-35.63 \pm 374.43$ \\
\hline \multirow{3}{*}{ Buzağıllama yılı* } & 2017 & 14 & $5540.77 \pm 1198.12^{\text {B }}$ & $-2478.09 \pm 896.25$ \\
\cline { 2 - 5 } & 2018 & 10 & $10496.96 \pm 1075.66 \mathrm{~A}$ & $2478.09 \pm 896.25$ \\
\hline \multirow{3}{*}{ Buzağılama mevsimi } & Sonbahar & 2 & $9013.99 \pm 1425.71$ & $995.12 \pm 1027.91$ \\
\cline { 2 - 5 } & Kı̧̧ & 8 & $6440.41 \pm 1291.33$ & $-1578.46 \pm 1297.77$ \\
\cline { 2 - 5 } & İlkbahar & 4 & $7878.01 \pm 1372.79$ & $-140.86 \pm 963.61$ \\
\cline { 2 - 5 } & Yaz & 10 & $8743.07 \pm 1110.00$ & $724.20 \pm 1084.16$ \\
\hline
\end{tabular}

*:P<0.05, A,B: Aynı sütunda farklı harflerle gösterilen ortalamalar arasındaki farklar önemlidir.

Buzağılama yılı dikkate alındığında üç yüz beş günlük süt verimi 2018 yılında 2017 yılına önemli derecede farklılık göstermiş, yaklaşık iki katına çıkmıştır. Bunda 2018 yılında hayvanlara sağlanan çevre faktörlerinin iyileşmiş olması yanında sürüye yeni hayvanlar katılmış olması da etkili olmuş olabilir. Ancak yine zikretmek gerekir ki değerlendirmeye alınan veri sayısı çok azdır. İşletmenin yeni kurulmuş olması bunda etkili olmuştur. Daha sonraki yıllarda hayvan sayısının artmasiyla birlikte bu değerlendirmelerin yeniden yapılarak işletmenin durumu kontrol edilmelidir. Dikkati çekebilecek diğer bir husus işletmedeki hayvanların çok azının 305 günlük süt verimlerinin bulunmasıdır. $\mathrm{Bu}$ da incelenen bazı özelliklerde mesela laktasyon sırasında grup sayısının farklı çıkmasına neden olmuştur. Diğer özelliklerde laktasyon sırası beş iken burada sadece üçüncü laktasyondaki hayvanların verisi değerlendirilebilmiştir.

Mevcut araştırmada elde edilmiş olan $6324.08 \pm$ 1769.29 kg'lık ortalama Halıcıoğlu (1989), Şekerden ve ark. (1989), Karakçı (1990), Djemali ve ark. (1992), Kaygısız (1997), Bakır ve Çetin (2001), Akkaş ve Şahin (2008) ve Şahin ve Ulutaş (2011),in Siyah Alaca sığırlar için bildirmiş oldukları değerlerden yüksek, Gürses ve Bayraktar (2012)'nin bildirmiş olduğu değerden düşük bulunmuştur.

\section{Sağımda Geçen Gün (SGG)}

Sağımda geçen gün (SGG) değerine ait elde edilmiş olan genel ortalama $178.62 \pm 23.53$ gün olarak tespit edilmiştir. Sağımda geçen gün (SGG) değerine ait EKKO, EM ve Standart Hata değerleri Çizelge 5'te verilmiştir.

Sağımda geçen gün (SGG) üzerine etkili faktörlere ait yapılmış olan varyans analizi sonucunda buzağı cinsiyetinin etkisi önemsiz bulunurken, laktasyon sırası, buzağılama yılı ve buzağılama mevsiminin etkisi $\mathrm{P}<0.01$ seviyesinde önemli bulunmuştur.

Sağılan gün sayısı bir sürüde, örneğin bu gün, bütün hayvanların laktasyonun kaçıncı gününde olduğunu ifade eder. Bireysel olarak SGG, sadece bir hayvanın 
sağılan gün sayısını veya laktasyonun kaçıncı gününde olduğunu gösterir. Ancak sürüde ortalama SGG, sürünün sağımda geçen gün sayısını gösterir. Başka bir ifadeyle sürüdeki hayvanların ortalama olarak bir yılda ne kadar sağıldığını gösterir. SGG için yıllık ortalamanın 160-170 gün olması gerekmektedir (Boztepe ve ark., 2015).

Yukarıdaki bilgilerin ışığında araştırmanın yapıldığ sürüde elde edilen $178.62 \pm 23.53$ günlük ortalama SGG değeri ideal değerden bir miktar yüksek çıkmıştır. $\mathrm{Bu}$ da yaklaşık olarak sürüde kızgınlıklardan yaklaşı olarak bir tanesinin kaçırıldığıını göstermektedir.

\section{Sağım Süresi}

Sağım süresi değerine ait elde edilmiş olan genel ortalama $342.048 \pm 139.107$ sn olarak tespit edilmiştir. Sağım süresi değerine ait EKKO, EM ve Standart Hata değerleri Çizelge 6'da verilmiştir.

Sağım süresine etkisi incelenen faktörlerden laktasyon sırası $\mathrm{P}<0.01$ seviyesinde önemli çıkmıştır. Buzağılama yılı ve buzağılama mevsiminin etkisi ise önemsiz bulunmuştur.

Çizelge 5. Sağımda geçen gün üzerine etkili faktörlere ait EKKO, EM ve SH değerleri

\begin{tabular}{|c|c|c|c|c|}
\hline Etkili Faktörler & SD & $\mathbf{N}$ & $\mathrm{EKKO} \pm \mathrm{SH}$ & $\mathrm{EM} \pm \mathrm{SH}$ \\
\hline \multirow{5}{*}{ Laktasyon sırası } & 1 & 70 & $194.90 \pm 7.50 \mathrm{a}$ & $57.46 \pm 20.88$ \\
\hline & 2 & 15 & $127.23 \pm 11.09^{\mathrm{c}}$ & $-10.20 \pm 9.67$ \\
\hline & 3 & 3 & $144.36 \pm 18.71^{b}$ & $6.92 \pm 12.33$ \\
\hline & 4 & 2 & $97.71 \pm 33.82 \mathrm{~d}$ & $-39.72 \pm 20.19$ \\
\hline & 5 & 6 & $122.98 \pm 30.99 \mathrm{c}$ & $-14.45 \pm 17.51$ \\
\hline \multirow{2}{*}{ Buzağı cinsiyeti } & Erkek & 51 & $138.17 \pm 16.08$ & $0.734 \pm 2.49$ \\
\hline & Dişi & 45 & $136.70 \pm 15.77$ & $-0.734 \pm 2.49$ \\
\hline \multirow{2}{*}{ Buzağılama yılı } & 2017 & 67 & $151.98 \pm 16.14^{\mathrm{a}}$ & $14.54 \pm 3.55$ \\
\hline & 2018 & 29 & $122.89 \pm 16.11^{b}$ & $-14.54 \pm 3.55$ \\
\hline \multirow{4}{*}{ Buzağılama mevsimi } & Sonbahar & 45 & $120.78 \pm 15.58^{b}$ & $-16.65 \pm 5.60$ \\
\hline & $\mathrm{K}_{1} \mathrm{~S}_{\mathrm{s}}$ & 10 & $128.02 \pm 15.24 \mathrm{~b}$ & $-9.41 \pm 8.77$ \\
\hline & İlkbahar & 4 & $151.02 \pm 22.43^{\mathrm{a}}$ & $13.58 \pm 10.60$ \\
\hline & Yaz & 37 & $149.92^{\mathrm{a}} \pm 16.23$ & $12.48 \pm 5.60$ \\
\hline
\end{tabular}

*:P<0.01, a,b: Aynı sütunda farklı harflerle gösterilen ortalamalar arasındaki farklar önemlidir

Çizelge 6. Sağım süresi EKKO, EM ve SH değerleri

\begin{tabular}{|c|c|c|c|c|}
\hline Etkili Faktörler & SD & $\mathrm{N}$ & $\mathrm{EKKO} \pm \mathrm{SH}$ & $\mathrm{EM} \pm \mathrm{SH}$ \\
\hline \multirow{5}{*}{ Laktasyon sirası** } & 1 & 86 & $292.84 \pm 32.32^{\mathrm{c}}$ & $-161.09 \pm 81.82$ \\
\hline & 2 & 19 & $376.53 \pm 43.69^{b}$ & $-77.41 \pm 44.58$ \\
\hline & 3 & 7 & $417.44 \pm 77.54 \mathrm{~b}$ & $-36.50 \pm 47.38$ \\
\hline & 4 & 7 & $436.92 \pm 111.80^{\mathrm{b}}$ & $-17.02 \pm 63.84$ \\
\hline & 5 & 6 & $745.98 \pm 132.87 \mathrm{a}$ & $292.03 \pm 81.92$ \\
\hline \multirow{3}{*}{ Buzağılama yılı } & 2016 & 18 & $425.85 \pm 67.10$ & $-28.08 \pm 26.83$ \\
\hline & 2017 & 78 & $474.33 \pm 58.89$ & $20.39 \pm 21.02$ \\
\hline & 2018 & 29 & $461.64 \pm 65.23$ & $7.69 \pm 24.92$ \\
\hline \multirow{4}{*}{ Buzağılama mevsimi } & Sonbahar & 56 & $441.29 \pm 57.80$ & $-12.65 \pm 23.99$ \\
\hline & Kiş & 20 & $487.78 \pm 68.36$ & $33.83 \pm 30.65$ \\
\hline & İlkbahar & 9 & $469.06 \pm 75.62$ & $15.11 \pm 40.69$ \\
\hline & Yaz & 40 & $417.64 \pm 62.77$ & $-36.30 \pm 23.98$ \\
\hline
\end{tabular}

$* *: \mathrm{P}<0.01, \mathrm{a}, \mathrm{b}:$ Aynı sütunda farklı harflerle gösterilen ortalamalar arasındaki farklar önemlidir

Laktasyon sırası incelendiğinde, en yüksek sağım süresi altıncı laktasyondaki hayvanlarda, en düşük sağım süresi ise birinci laktasyondaki hayvanlardan elde edilmiştir. Laktasyon sırasının artmasıyla sağım süresi de artmıştır. Sağım süresine ait genel ortalama $342 \mathrm{sn}(5.7 \mathrm{dk})$, oksitosin hormonunun etki süresi olan 5-7 dakikalık süre içerisindedir. Yani sütün indirilmesi için yaklaşık 5-7 dk'llk süre gereklidir. Süt bu 5-7 dk içerisinde alınmalıdır. Ancak bazı hayvanlar yavaş sağım hızına sahip olabilirler. Bu nedenle sağım süresi artış gösterebilir. Tam tersi yani bazı hayvanlar da yüksek sağım hızına sahip olabilirler. Bu nedenle sağımları daha erken biter. Sağım hızı normal olan hayvanlarda bu süre 5-7 dk kadardır. Çok yavaş sağılan hayvanlar sağımhanede geçen süreyi uzatacağı gibi, çok hızlı sağılan hayvanlarda iş akışını aksatabilir. Bu nedenle genellikle hayvanların bu 5-7 $\mathrm{dk}$ içerisinde sağılmaları uygundur.

\section{Elektrik İletkenliği}

Sütün elektrik iletkenliğine ait EKKO ve Sh değeri $5.0677 \pm 0.5255 \mathrm{mS} / \mathrm{cm}$ olarak tespit edilmiştir. 
İletkenlik değerine ait EKKO, EM ve Standart Hata değerleri Çizelge 7'de verilmiştir.
Elektrik iletkenliğine etkisi incelenen faktörlerden laktasyon sırası, buzağılama yılı ve buzağılama mevsiminin etkisi önemsiz çıkmıştır.

Çizelge 7. Sütün Elektrik İletkenliğine ait EKKO, EM ve Sh değerleri

\begin{tabular}{|c|c|c|c|c|}
\hline Etkili Faktörler & & $\mathbf{N}$ & $\mathrm{EKKO} \pm \mathrm{SH}$ & $\mathrm{EM} \pm \mathrm{SH}$ \\
\hline \multirow{5}{*}{ Laktasyon sirası } & 1 & 86 & $5.1837 \pm 0.1229$ & $0.3759 \pm 0.3124$ \\
\hline & 2 & 19 & $5.1555 \pm 0.1653$ & $0.3476 \pm 0.1675$ \\
\hline & 3 & 7 & $4.9200 \pm 0.2939$ & $0.1122 \pm 0.1791$ \\
\hline & 4 & 7 & $4.7728 \pm 0.4228$ & $-0.0349 \pm 0.2412$ \\
\hline & 5 & 6 & $4.0069 \pm 0.5126$ & $-0.8008 \pm 0.3177$ \\
\hline \multirow{3}{*}{ Buzağılama yılı } & 2016 & 18 & $4.9217 \pm 0.2549$ & $0.1139 \pm 0.1013$ \\
\hline & 2017 & 78 & $4.7650 \pm 0.2256$ & $-0.0427 \pm 0.0796$ \\
\hline & 2018 & 29 & $4.7365 \pm 0.2481$ & $-0.0712 \pm 0.0939$ \\
\hline \multirow{4}{*}{ Buzağılama mevsimi } & Sonbahar & 56 & $4.8469 \pm 0.2202$ & $0.0390 \pm 0.0907$ \\
\hline & $\mathrm{K}_{1 / S}$ & 20 & $4.6612 \pm 0.2606$ & $-0.1465 \pm 0.1156$ \\
\hline & İlkbahar & 9 & $4.8848 \pm 0.2887$ & $0.0770 \pm 0.1536$ \\
\hline & Yaz & 40 & $4.8382 \pm 0.2377$ & $0.0304 \pm 0.0914$ \\
\hline
\end{tabular}

Sütün elektrik iletkenliği ile mastitis arasında ilişki bulunmaktadır. Sütün elektrik iletkenliğinin artması, süte sodyum ve klor iyonlarının geçişi ile olmaktadır. $\mathrm{Bu}$ da vücutta bir patojen olduğunun göstergesi olarak kabul edilmektedir. Yani mastitisin teşhisinde sütteki elektrik iletkenliğinin durumuna bakılarak bir ön değerlendirme yapılabilmektedir. Yetiştiricilik açısından önemli bir husus elektrik iletkenlik değeridir. Normal sütte elektrik iletkenlik değeri 4-5.5 $\mathrm{mS} / \mathrm{cm}$ olarak kabul edilmektedir (Boztepe ve ark. 2015).

Mevcut araştırmada elde edilen $5.0677 \pm 0.5255$ $\mathrm{mS} / \mathrm{cm}^{\prime}$ 'lik EI'lik değeri uluslararası standart olan $4^{-}$ $5.5 \mathrm{mS} / \mathrm{cm}$ 'lik sinırlar içerisindedir.

Firk ve ark. (2002), süt sığırlarında aktivite, süt verimi, süt akış hızı ve sütün iletkenlik değerlerine sistematik etkiler üzerine yaptıkları çalışmada, laktasyon sirasinin artması sonucu aktivitenin azaldığını, süt veriminin, süt akış hızının ve süt iletkenlik değerinin yükseldiğini ifade etmişlerdir. Mevcut araştırmada iletkenlik değeri üçüncü laktasyona kadar artış göstermiş, bundan sonra azalmaya başlamıştır.

Timurkan (2004), ineklerde yaş ve ırkın sütün elektrik iletkenliği (EI) üzerine etkisini belirlemeyi amaçladığ çalışmasında, kullanılan aynı ırklar arasında sütün Eİ yönünden bir farklılık bulunmamış, ancak aynı ırk içindeki hayvanların 8-14 yaş aralığındaki hayvanlarinda $(\mathrm{P}<0.05)$ ve meme loblarinda $(\mathrm{P}<0.01)$ EI bulguları, uluslararası standartların belirlediği 5.6 $\mathrm{mS} / \mathrm{cm}$ 'nin üzerinde tespit edilmiştir.

İneklerde sütün elektrik iletkenliği (EI) ve California Mastitis Testinin (CMT) karşılaştırılması ve öneminin ortaya konulması amacıyla yapılan çalışmada, materyal olarak kullanılan ineklerin +1 derecede CMT'ye pozitif sonuç verdiği ve bu hayvanların meme loblarındaki sütün elektrik iletkenliğinin ise $5.81 \pm$
$0.06 \mathrm{mS} / \mathrm{cm}$ olduğu tespit edilmiştir. Yani, CMT sonuçlarıyla sütün Eİ sonuçlarının uyumsuz olduğu bildirilmiştir (Timurkan, 2014).

\section{SONUÇ}

Araştırmada Konya ili Karapınar ilçesinde bulunan ve yaklaşık üç yıldır süt sığırcılığı yapan özel bir işletmenin süt ve döl verim özellikleri incelenmiş ve elde edilen bulgular doğrultusunda öneriler sunulmuştur. $\mathrm{Bu}$ çalışmada sadece süt verim özellikleri sunulmuştur. Konya bölgesi Türkiye'nin önemli sığırcılık bölgelerinden birisidir. Bu nedenle zaman zaman işletmelerin kendilerini kontrol etmesi ve incelenen özellikler bakımından olumsuzluklar olması durumunda bunları düzeltmeleri gereklidir. Sürü yönetiminin düzenli olması hem işletmenin karını artıracak hem de ülke ekonomisine katkılar sağlayacaktır. Dolayısıyla bu tip çalışmaların zaman zaman işletmeler bünyesinde yapılması önem arz etmektedir. Çalışmada elde edilen sonuçlara göre incelenen özelliklerden bazılarında problemler olduğu görülmüştür. $\mathrm{Bu}$ doğrultuda işletmenin bazı konularda sürü yönetiminde düzenlemeler yapması gereklidir. Böylece daha verimli bir şekilde çalışmaları sağlanmış olacaktır.

\section{KAYNAKLAR}

Akkaş Ö, Şahin E H 2008. Holştayn Irkı Sığırlarda Bazı Verim Özellikleri. Kocatepe Veteriner Dergisi, 1: 25-31.

Anonim 2018. TÜİK Hayvancılık İstatistikleri. http://tuikapp.tuik.gov.tr/hayvancilikapp/hayvanci lik.zul, (Erişim tarihi: 05.03.2019).

Bakır G, Çetin M 2001. Reyhanlı Tarım işletmesinde Yetiştirilen Siyah Alaca Sığırlarda Döl ve Süt Verim Özellikleri. Turk Journal and Veterinary Animal Sciences, 27: 173-180.

Boztepe S, Aytekin İ, Zülkadir U 2015. Süt Sığırcılığı. Selçuk Üniversitesi, Konya. 
Djemali M, Berger PJ 1992. Yield and Reproduction Characteristics of Friesian Cattle Under North African Conditions. Journal of Dairy Science, 75, 12,3568-3575.

Düzgüneş O, Kesici T, Kavuncu O ve Gürbüz F 1993. Araştırma ve Deneme Metotları (İstatistik Metodları II) AÜ Ziraat Fakültesi Yayın No: 1021, Ders kitabı, 295.

Firk R, Stamer E, Junge W ve Krieter J 2002. Systematic effects on activity, milk yield, milk flow rate and electrical conductivity, Archives Animal Breeding, 45 (3), 213-222.

Gürses M, Bayraktar M 2012. Türkiye'de Farklı Bölgelerde Yetiştirilen Holştayn Sığırlarda Bazı Süt ve Döl Verimi Özellikleri. Kafkas Üniversitesi Veteriner Fakültesi Dergisi, 18 (2): 273-280.

Halıcıoğlu V 1989. Karacabey Tarım İşletmesinde Yetiştirilen Değişik Kaynaklı Siyah Alaca Sığırların Döl ve Süt Verimi Özellikleri Üzerinde Karşılaştırmalı Araştırmalar. İstanbul Üniversitesi Sağlık Bilimleri Enstitüsü, Doktora Tezi, İstanbul.

Harvey W 1987. User's Guide For LSMLMW PC-1 Version Mixed Model, Least and Maximum Likelihood Computer Program. Ohio State University, Columbus, Mimeo.

Kaya İ, Kaya A 2003. Siyah Alaca Sığırlarda
Laktasyonun Devamlılık Düzeyine Ait Parametre Tahminleri ve Süt Verimi ile İlgisi Üzerinde Araştırmalar I. Laktasyonun Devamlılık Düzeyini Etkileyen Faktörler, Hayvansal Üretim 44 1, 76-94.

Kaygısız A 1997. Siyah Alaca Siğırların Kahramanmaraş Tarım İşletmesi Şartlarındaki Verim Özellikleri. Ankara Üniversitesi Ziraat Fakültesi Tarım Bilimleri Dergisi, 3 2, 9-22.

Şahin A, Ulutaş Z 2011. Tahirova Tarım İsletmesinde Yetiştirilen Siyah Alaca İneklerde Süt ve Döl Verim Özelliklerini Etkileyen Bazı Çevresel Faktörler. Anadolu Tarım Bilimleri Dergisi, 26 (2):156-168.

Şekerden Ö, Özkütük K, Pekel E 1989. Gelemen Taran İşletmesi Siyah Alaca Sığır Populasyonu Verim Özellikleri. 1. Döl Verim Özellikleri. Çukurova Üniversitesi Ziraat Fakültesi Dergisi, 4,27-36.

Timurkan H 2004. Ineklerde yaş ve ırkın sütün elektriksel iletkenliği üzerine etkisi. DAUM Dergisi, 2: 55-58.

Timurkan H 2014. Ineklerde california mastitis testi ve sütün elektrik iletkenliğinin karşılaştırılması, Fırat Üniversitesi Sağlık Bilimleri Veteriner Dergisi, 28 (3), 135-136.

Uzman EE 2000. "Et ve Et Ürünleri”, Türkiye Kalkınma Bankası, Sektörel Araştırmaları, Temmuz 2000, Ankara. 